\title{
QUALIFYING FEATURES OF THE COMPOSITION OF EVASION FROM PAYMENT OF SINGLE FEE FOR OBLIGATORY STATE SOCIAL INSURANCE AND INSURANCE CONTRIBUTIONS FOR OBLIGATORY STATE PENSION INSURANCE AND DELIMITATION FROM RELATED OFFENCES
}

\section{Predmestnikov O. G.}

\section{INTRODUCTION}

The qualifying signs of a crime in criminal law are those that indicate an increased public danger of the act, in comparison with the signs described in the main part of the crime.

\section{Qualifying features of the composition of evasion from payment of the single contribution to compulsory state social insurance} and insurance contributions to compulsory state pension insurance

It should be noted that qualifying signs of evasion from payment of a single contribution to compulsory state social insurance and insurance contributions to compulsory state pension insurance (part 2 of article 2121 of the criminal code of Ukraine) take place when: first, the same acts are committed by prior agreement by a group of persons; secondly, if they (the same actions) lead to the actual non-receipt of funds in large amounts in the funds of compulsory state social insurance.

The Commission of a crime by prior conspiracy by a group of persons is a form of complicity. The content of this form of complicity by the legislator is defined in part 2 of article 28 of the criminal code of Ukraine. A crime is recognized as committed by a group of persons by prior agreement, if it was jointly committed by several persons (two or more), who in advance, that is, before the beginning of the crime, agreed on its joint Commission. Thus complicity in Art. 26 of the criminal code is defined as deliberate joint participation of several subjects of a crime in Commission of an intentional crime.

In the resolution of the Plenum of the Supreme Court of Ukraine dated 08.10.2004 No. 15 "on some issues of application of the legislation on liability for evasion of taxes, fees and other mandatory payments" $"$ it is noted

\footnotetext{
${ }^{1}$ Kurash Y. Criminal liability for evasion of taxes, fees and other mandatory payments (analysis of the crime): abstract. Dis. for the Sciences. The degree candidate. Yuri. Sciences: spec. 12.00.08 "Criminal law and criminology; criminal Executive law". Kharkov, 1998. 18 p.
} 
that such a qualifying sign of intentional evasion of taxes, fees and other mandatory payments (including and for obligatory state social insurance and pensions) as this crime on preliminary arrangement by group of persons, applies only in the case when it participated as coauthors two or more persons who previously to the act, have agreed not to pay taxes, charges, other obligatory payments to the budgets or state trust funds or to pay them in full. On this basis can be qualified, in particular, the actions of officials of the same enterprise, institution, organization, which is responsible for the correctness of the calculation and payment of taxes, fees, other mandatory payments and for the reliability of the relevant reporting (for example, the head and chief accountant of the legal entity-the payer of the insurance premium on compulsory state pension insurance, who sign documents submitted to the social insurance funds).

Analysis p. 9 the foregoing resolution gives reason to conclude that the actions of the heads of enterprises, institutions, organizations, who gave a subordinate official persons order, a command, an order to sign or submit to the bodies of PFCs false (falsified) reports, balances, declarations, payments or to pay insurance premiums for obligatory state pension insurance or to pay them in full, as well as the actions of officials that performed such an illegal order, instruction or order, must qualify according to art. 2121 of the criminal code as the actions of the perpetrators of this crime, committed by prior agreement by a group of persons. Whereas the actions of employees of enterprises, institutions, organizations that are not officials (and therefore are not the subjects of the crime under art. 2121 of the criminal code of Ukraine) and by orders, instructions, orders of officials responsible for the correctness of calculation and timeliness of payment of insurance premiums for compulsory state pension insurance, made false information in the documents of primary accounting or in reports, balances, declarations, calculations, shall be qualified as aiding deliberate evasion of payment of these payments for part 5 of article 27 and for that part of article 2121 of the criminal code of Ukraine, which qualified the actions of an official who gave an illegal order, instruction, order. It is necessary to take into account the provisions of art. 41 of the criminal code of Ukraine concerning legal consequences of execution of the order or the order.

Therefore, we can conclude that the highest court characterizes this aggravating circumstance as the Commission of evasion from payment of single fee for obligatory state social insurance and insurance contributions for obligatory state pension insurance on preliminary arrangement by group of persons the following interrelated factors: a) evasion from payment of single fee for obligatory state social insurance and insurance contributions for obligatory state pension insurance, committed by two or more persons, 
b) the existence of a preliminary agreement not to pay insurance premiums for compulsory state social and pension insurance, achieved by them before committing the crime; c) persons involved in the Commission of evasion of payment of insurance premiums for compulsory state social and pension insurance, have all the signs of the subject of this crime.

With observance of the above requirements Lisichansk city court of the Luhansk region was brought to criminal responsibility of the acting Director and the chief accountant of separate division "named G. Kapustina "JSC "Lisichanskugol", which by prior agreement among themselves, in order to evade payment of insurance premiums for compulsory state pension insurance, with full and timely accrual and retention of mandatory insurance premiums, did not ensure timely transfer of mandatory insurance premiums in full to the Pension Fund of Ukraine In the city of Lisichansk ${ }^{2}$.

V. Lysenko, P. Melnik, P. Andrushko, Y. Sukhov, Y. Kurash, V. Ostanin express a bit similar to Commission of a crime on preliminary arrangement by a group of persons in the context of evasion from payment of obligatory contributions to the state. Thus, P. Andrushko, commenting on the specified qualifying sign, notes that, as a rule, subjects of this qualified structure of a crime will be the head and the chief accountant of the legal entity-the payer of obligatory contributions to the state, which signed the documents, submitted to state bodies. Thus, the scientist denies possibility of Commission of evasion from payment of obligatory contributions to the state on preliminary arrangement by group of persons physical persons to whom the law is assigned to pay such contributions, including the persons who are engaged in business activity. According to P. Andrushko, individuals who are legally obliged to pay mandatory contributions to the state, and private entrepreneurs pay taxes, fees, other mandatory payments, including on obligatory state social insurance individually, from own incomes, for this reason they cannot be executors (co - executors) evasion from payment of obligatory payments made by other payer of obligatory payments ${ }^{3}$.

It seems that the above position is not quite correct, given the following: in accordance with the legislation on compulsory state social insurance, the obligation to pay mandatory payments, keep records of income and expenses, report to the authorized bodies is imposed not only on payers individuals and private entrepreneurs, but also on their representatives: auditors, relatives, accountants, other authorized persons, and the like.

2 Lesniewski-Kostareva T. Differentiation of criminal responsibility. Theory and legislative practice. Moscow: NORMA, 2016. P. 230.

${ }^{3}$ Leykina N. Personality of the criminal and criminal responsibility. L.: Publishing house University press, 1968. P. 129. 
Evasion of the specified payers of obligatory contributions from their payment on preliminary arrangement with the representatives, in our opinion, it is necessary to qualify as made on preliminary arrangement by group of persons.

As it was noted earlier, the legislator clearly defined that the previous is considered a conspiracy that was achieved by the accomplices of the crime in advance, that is, before the crime began. Y. Kurash does not agree with this position, who believes that the collusion on joint evasion of mandatory payments can be achieved in the process of attempted murder.

The crime, and not only before the beginning of the Commission of the crime. ${ }^{4}$ This issue was the object of a rather long scientific discussion at the stage of reforming the legislation on criminal responsibility, which with the adoption of the current criminal code of Ukraine was correctly solved by the legislator.

Deliberate joint participation of several subjects of a crime in Commission of an intentional crime considerably increases public danger of the committed act as at mutual and in advance stipulated help each other criminals have much more opportunities in realization of the criminal intentions, and in some cases only Association of efforts of several criminals gives the chance to make this or that crime as the criminal result is unattainable for each of them separately.

As N. Melnik notes, "the main feature of the community of actions (without-activity) of accomplices is that the actions (inaction) of each of them are an integral part of the overall activity of committing a crime. They act together, contributing to the Commission of the crime. The actions (inaction) of each accomplice under specific circumstances are a necessary condition for the Commission of criminal actions (inaction) by another accomplice, and, in the end, - a necessary condition for the occurrence of the overall criminal result" 5 .

In addition to the community of actions (inaction), complicity is characterized by a subjective relationship between the accomplices, namely the General attitude to the act committed by them and the consequences of such an act. The feature of smart time the intent of the partners is to get to know each of them socially dangerous character as their personal acts and the acts of all other partners. At the same time, the accomplices must

${ }^{4}$ Ostanin V. Qualification of evasion from payment of taxes, fees, other obligatory payments: autoref. dis. for the Sciences. The degree candidate. Yuri. Sciences: spec. 12.00.08 "Criminal law and criminology; criminal Executive law". Kiev, 2004. 20 s.

${ }^{5}$ Leykina N. Personality of the criminal and criminal responsibility. L.: Publishing house University press, 1968. P. 129. 
consciously foresee the onset or possibility of socially dangerous consequences as the result they desired.

The volitional moment of intent of accomplices is characterized by the desire or conscious assumption of a single criminal result for all accomplices. At the same time, the motives and goals of all accomplices do not necessarily have to be the same.

In the domestic criminal law science and judicial practice, the qualifying sign "the Commission of a crime by prior agreement by a group of persons" is usually understood as coop, that is, when all the accomplices are directly involved in the implementation of the objective side of the evil. This understanding of the specified aggravating circumstance were established by the Soviet criminal law doctrine. Yes, F. Burchak, R. Galiakbarov, P. Telnov justified the position that increasing the degree of public danger of the crime on preliminary arrangement by group of persons is carried out primarily through a combination of the location and the time the efforts of several persons who directly perform the steps described in the article of the criminal code, i.e. act as co-executors. This combination of efforts of several co-perpetrators, according to the authors of this position, significantly increases the effectiveness of the Commission of evil, reduces the possibility of resistance on the part of victims or other persons, contains a threat of causing greater harm to protected interests. On the basis of this aggravating circumstance "committing a crime on preliminary arrangement by group of persons" were asked to define as a crime, which co-involves two or more persons who in advance of the act, have agreed to jointly committed.

A different position is taken by the authors of one of the scientific and practical comments of the criminal code of Ukraine, who note that members of a group of persons by prior collusion can be both perpetrators and accomplices of various types (organizers, instigators, accomplices).

$\mathrm{N}$. Gutorova believes that the approach to understanding "the Commission of evil by prior collusion by a group of persons" as co-execution is insufficiently justified. In her opinion, significant improvements in the degree of public danger of the crimes committed are directly involved a few people, you can only talk about the violent crimes, because in such cases the combined efforts of subcontractors at the place and time facilitates the implementation of the infringement, including by reducing possibilities for resistance by the victim or other persons When committing the same non-violent crimes, including and against the public finances, the presence of several perpetrators cannot be a factor of significant increase in public danger compared to the Commission of an act in complicity with the distribution of roles. For example, the head of the company that avoids taxes, duties and other mandatory payments, participation in the crime accomplice, which will 
provide information on "effective schemes of tax evasion" and to encourage their use (creation of fictitious business entities, using Bank accounts located in offshore zones, etc.) is much "healthier" than participation as co-executor of the chief accountant of the enterprise.

In our opinion, this perception is considered aggravating circumstance is the most reasonable, and consequently evasion a single fee for obligatory state social insurance and insurance contributions for obligatory state pension insurance, committed on preliminary arrangement by group of persons, should be understood as such that was committed on a preliminary agreement reached prior to the Commission of the crime two or more persons who are endowed with characteristics of a subject of this crime and acted as on pugilist and roles.

Another qualifying sign of evasion from payment of the single contribution to compulsory state social insurance and insurance contributions to compulsory state pension insurance is the Commission of the same acts, if they led to the actual non-receipt of funds in large amounts to the funds of compulsory state social insurance.

In accordance with the note to article 2121 of the criminal code of Ukraine, a large amount of funds should be understood as the amount of a single contribution to compulsory state social insurance and insurance contributions to compulsory state pension insurance, which are three thousand times or more high than the non-taxable minimum income of citizens established by legislation.

An example of the Commission of the crime we are considering on a large scale is the following. PERSON_2, realizing the criminal intention directed on evasion from payment of insurance premiums on obligatory state pension insurance in Pension Fund of Ukraine, holding a position of the chief accountant of zgp "Radiopribor", acting intentionally, during the period from February 01, 2013 to August 31, 2013, in violation of requirements of item $1 \mathrm{~h} .1$ art. 4 of the Law of Ukraine "on collection and accounting of a single contribution to compulsory state social insurance" No. 2464-VI of July 08, 2010 "...the payers of the single contribution are employers-enterprises, institutions, organizations established in accordance with the legislation of Ukraine, regardless of ownership, type of activity and management...", in violation of the requirements of paragraph 1, part 2 of article 6 of the said Law "... the single contribution payer is obliged to pay the single contribution in full and on time..."and in violation of the requirements of part 12 of art. 9 of the same Law. "a single contribution is payable regardless of the financial condition of the payer "and"... obligations to pay a single contribution are performed first and have priority over all other obligations, except for obligations regarding the payment of wages (income).."., being aware of the actual financial condition of the enterprise 
and having a real opportunity to pay the debt on payment of insurance premiums for compulsory state pension insurance to the Pension Fund of Ukraine, evaded their payment, by transferring funds to the current accounts of counterparties, re- considered funds for the needs of a commercial nature, which led to the actual non-receipt of funds in the Pension Fund for a total of 2497672,96 UAH.

Thus, as a result of criminal acts PERSON_2 in the Pension Fund of Ukraine actually did not receive funds in large amounts totaling 2497672,96 $\mathrm{UAH}$, which is more than 3000 times higher than the statutory tax-free minimum income of citizens.

Their illegal intentional actions PERSON_2 committed a criminal offense under part 2 of article 2121 of the criminal code of Ukraine, which is qualified as intentional evasion of payment of insurance premiums on compulsory state pension insurance, committed by an official of the enterprise, which led to the actual non-receipt of funds in large amounts to the Pension Fund of Ukraine ${ }^{6}$.

In our opinion, the definition of the qualifying feature of the crime under consideration by us with the help of the minimum income of citizens is not quite successful, at least given the fact that this indicator is not stable and is subject to frequent changes, which can lead to confusion and improper application of criminal law.

Criminal consequences and evaluative concepts in them have been studied by different scientists (in particular, P. Berzin, M. Panov, V. Pitetsky, S. Shapchenko), but have not been solved until now. Thus, since 2005-in addition to the criminal code of Ukraine Art. 2121, the tax-free minimum income of citizens (in terms of qualification of crimes or administrative offenses) has changed annually, which was due to economic processes that occurred in the country and the world as a whole. It should be noted that earlier the legislation for all cases applied the tax-free minimum income of citizens, the size of which was 17 UAH. Subsequently, the legislator made the binding of the tax-free minimum income of citizens (in terms of qualification of crimes or administrative offenses) to the minimum wage, and then this indicator began to be calculated on the basis of the subsistence minimum. For all other cases not connected with application of norms of the criminal and administrative legislation regarding qualification of crimes or administrative offenses, the tax-free minimum of the income of citizens remains invariably stable and, as earlier, makes $17 \mathrm{UAH}$.

\footnotetext{
${ }^{6}$ Kurash Y. Criminal liability for evasion of taxes, fees and other mandatory payments (analysis of the crime): abstract. dis. for the Sciences. the degree candidate. Yuri. Sciences: spec. 12.00.08 "Criminal law and criminology; criminal Executive law". Kharkov, 1998. 18 p.
} 
As you can see, during the existence of article 2121 of the criminal code of Ukraine, the concept of a large size when evading the payment of a single contribution to compulsory state social insurance and insurance contributions to compulsory state pension insurance was determined by various criteria and repeatedly changed. The change in the concept of "large size" when evading the payment of mandatory contributions to the state can be traced since the introduction of the legislation of Ukraine on criminal liability of such a feature. For the first time the concept of "large size" was used by the legislator in the text of the disposition of art. 1482 "Evasion from payment of taxes from the enterprises and the organizations" UK of Ukraine of 1960 in edition of the Law of Ukraine of 26.01.1993 for determination of the material size of consequences of a crime. This version of the article did not contain criteria for determining the large amount of damage caused to the state, since at that time this concept was estimated.

In a note to article 1482 "tax Evasion" of the criminal code of Ukraine 1960 in the second edition of 28.01.1994, the legislator determined that a large amount should be understood as the amount of tax, which is a hundred times or more high than the minimum wage, but does not exceed this amount a thousand times. Note to this article in the third edition of 05.02.1997 the large amount of funds that have not been received by the budgets and state trust funds, determined the amount of taxes, fees and other mandatory payments, which is two hundred and fifty times or more higher than the statutory tax-free minimum income of citizens, but, at the same time, did not exceed it a thousand times. This edition of Art. 1482 of the criminal code of Ukraine of 1960 for the first time defined the large size as the qualifying sign of this crime.

After the adoption of the new criminal code, a large amount of evasion of mandatory contributions to the state was contained in a note to article 212 "Evasion of taxes, fees and other mandatory payments", according to which a large amount of funds was understood as the amount of taxes, fees and other mandatory payments, which are three thousand or more times higher than the minimum income of citizens, which is not taxed by legislation. It is this edition and was taken as a basis for determining the large size of the crime under part 2 of article 2121 of the criminal code of Ukraine.

As we can see, since the introduction of the concept of "large scale" in the legislation of Ukraine on criminal liability to determine the amount of damage caused to the state by evasion of mandatory contributions, its quantitative index has increased significantly. From the amount of money, which is one hundred and more times higher than the minimum wage in 1994, to the amount, which is three thousand and more times higher than the statutory non-taxable minimum income of citizens in 2016. 
An interesting proposal was once made by V. Vereskov, who proposed to establish, along with the absolute criterion for determining the evaluation concepts (significant, large and especially large sizes), also a relative criterion that would be determined depending on the part of unpaid mandatory contributions, which would make it possible to overcome the existing inequality of conditions of large and small enterprises ${ }^{7}$. With proper economic justification, this approach to deepening the differentiation of responsibility is quite acceptable. Another area of differentiation of liability may be the difference between the payers of a single contribution to compulsory state social insurance and insurance contributions to compulsory state pension insurance or methods of evasion. Also, when reforming the legislation on criminal liability in this direction, it is necessary to pay due attention to the discrepancy between the punishment and the losses inflicted.

In addition to aggravating circumstances, article 2121 of the criminal code of Ukraine contains and particularly aggravating circumstances, namely Commission of this crime by a person previously convicted of evasion from payment of single fee for obligatory state social insurance or of insurance premiums on obligatory state pension insurance, as well as evasion, which led to the actual shortfall in funds of obligatory state social insurance funds in especially large sizes, that is, in size, in five thousand times and more exceed statutory non-taxable minimum incomes of citizens (CH. 3 Art. 2121 of the criminal code of Ukraine).

This is particularly aggravating feature of the crimes as "acts stipulated by the first or second part of this article, teach a person previously convicted of evasion from payment of single fee for obligatory state social insurance or of insurance premiums for obligatory state pension insurance", evidence of recidivism in the act of the perpetrator. At the same time, according to art. 34 criminal code of Ukraine recidivism shall be Commission of new intentional crime by a person who has been convicted for a deliberate crime, i.e. a person who already has a conviction for a previous intentional crime and again commits a deliberate crime.

It should be noted that in part 3 of article 2121 of the criminal code of Ukraine we are talking about the so-called special relapse, which occurs when a person, having a criminal record for a certain intentional crime, again commits a deliberate evil-rank, which by its legal nature is identical or, in cases provided by law, homogeneous, that is, in both cases, it encroaches on

7 Sukhov Y. Evasion of taxes, fees, other mandatory payments: problems of differentiation from related crimes and qualification in aggregate: abstract. Dis. for the Sciences. The degree candidate. Yuri. Sciences: spec. 12.00.08 "Criminal law and criminology; criminal Executive law". Kiev, 2000. P. 16. 
the same object. The increased public danger of a special relapse, due to which it acts as a particularly qualifying sign of evil-rank is that a new act in the form of evasion of payment of a single contribution to compulsory state social insurance and insurance contributions to compulsory state pension insurance, a person commits again after her conviction, prosecution and sentencing for a similar evil-rank.

According to Art. 88 of the criminal code, a person is recognized as having a criminal record from the date of entry into force of the conviction and until the repayment or removal of the criminal record. At qualification of evasion from payment of the uniform contribution on obligatory state social insurance and insurance contributions on obligatory state pension insurance for part 3 of Art. 2121 of the criminal code of Ukraine made by the person earlier judged for such crime, it is necessary to establish the following conditions: a) a conviction for a first offense, not withdrawn and not repaid in accordance with the law, along; b) for a first offense the person is convicted with sentencing and was not exempted from punishment; c) the criminality and punishability of the acts for which we convicted person is not fixed by law. Failure to comply with these conditions allows to qualify the actions of a person under part 3 of article 2121 of the criminal code of Ukraine.

\section{Delineation of the composition of evasion from payment of a single contribution to compulsory state social insurance and insurance contributions to compulsory state pension insurance from related crimes}

The analysis of objective and subjective signs of structure of evasion from payment of insurance premiums on obligatory state pension insurance allows passing to questions of differentiation of this crime from adjacent structures of crimes.

According to the structure of the crime under article 2121 "Evasion of payment of a single contribution to compulsory state social insurance and insurance contributions to compulsory state pension insurance" of the criminal code of Ukraine, such a crime under article 212 "Evasion of taxes, fees (mandatory payments)" of the Code. Such a situation. Marin explains the presence in the criminal legislation of two norms, one of which is General (defines a certain range of acts as crimes), the other-special (distinguishes from this circle of certain actions as independent crimes, providing criminal law regulation), according to which in the criminal law assessment of one socially dangerous act, both these norms claim to be applied. The competition of General and special criminal law norms in the qualification of an act arises through the desire of the legislator to differentiate criminal responsibility, distinguishing from the General norm a 
special norm (norms), which provides for a more strict or more lenient responsibility in comparison with the General norm ${ }^{8}$.

A somewhat similar differentiation of responsibility for the payment of mandatory payments to the state when evading their payment took place in the case of articles 212 and 2121 of the criminal code of Ukraine. So, the legislator at first allocated from tax relations the relations on obligatory state pension insurance, and subsequently-and all relations on obligatory social insurance and for their criminal legal protection added UK of Ukraine Art. 2121.

Comparison of General and special norms shows that the General norm is large in scope, that is, it covers a larger range of acts than the special one, but the latter contains more features, due to which it stands out from the General one. In cases of competition between General and special norms, the law of the inverse relationship between the object and the content of the concept is clearly manifested. In particular, the concept of a special criminal law norm: with the increase in the number of features enshrined in the law on criminal responsibility, respectively, the range of public relations that are amenable to criminal law protection decreases, and thus-the volume of regulation (impact) of a special criminal law norm.

It is necessary to agree with A. Marin that for the correct resolution of competition of the General and special norms the classification of special norms and, as a consequence, - classification of types of competition within a ratio of the General and special norms is important. Also suitable in the context of the competition of criminal law is the position of M. Svidlov, who proposed three bases for the classification of the following norms: the subject of criminal law regulation, its borders and the object of protection. For the subject, he distinguishes such rules: absolutely special, which include special rules providing for responsibility for attacks, homogeneous with the provided General rule and relatively special, distinguished from several General, as well as those that, although they were isolated from one General rule, but provide for responsibility for behavior that was not previously regulated by criminal law. The object of protection, he highlighted the two types of rules: special rules, has the same General basic object (a single), and special, different in object from the respective total, that is having the primary and secondary object ${ }^{9}$.

\footnotetext{
${ }^{8}$ Resolution of the Plenum of the Supreme Court of Ukraine dated 08.10.2004 No. 15 "on certain issues of application of legislation on liability for evasion of taxes, fees and other mandatory payments". URL: http://zakono.rada.gov.ua/cgi-bino./laws/maino.cgi?regno.= v0015700-04.

9 Sukhov Y. Evasion of taxes, fees, other mandatory payments: problems of differentiation from related crimes and qualification in aggregate: abstract. dis. for the Sciences. the degree candidate. Yuri. Sciences: spec. 12.00.08 "Criminal law and criminology; criminal Executive law". Kiev, 2000. P. 16.
} 
In the criminal law literature, it is unanimously proposed to apply only a special norm in the competition of General and special rules. The correctness of this statement is not in doubt, since the decision of this type of competition is based on the will of the legislator, who, highlighting a special rule, pointed out that in the presence of signs provided for by a special rule, it is a special rule that should be applied. However, if there is no special norm in the act, the General norm is applied instead. Simultaneous qualification under the General and special rules is possible only in the case of a real set of crimes.

When comparing the elements of the composition of the investigated crime with the elements of the crime under article 212 of the criminal code of Ukraine, the main differences can be traced in such elements of the crime, as the direct object and object of the crime ${ }^{10}$. These elements of the specified structures of crimes essentially differ in the contents and properties and are those signs on which it is necessary to distinguish the specified structures of crimes from each other.

The direct object of the crime under article 2121 of the criminal code of Ukraine is the procedure for payment of insurance premiums established by law, which ensures the formation of funds of compulsory state social insurance funds. The direct object of the crime, pre - saw the article 212 of the criminal code of Ukraine is established by the legislation order of taxation of physical and legal entities Subject to avoidance of evil, the rite, under the article. 2121 of the criminal code of Ukraine, there are funds that have been paid as a single contribution to compulsory state social insurance and insurance contributions to compulsory state pension insurance. The subject of the crime under article 212 of the criminal code of Ukraine is money that must be paid to the budgets of various types as taxes, fees (mandatory payments).

The above indicates that article 212 and article 2121 of the criminal code of Ukraine are not in competition with the General and special rules, because they have different objects and subject. However, on the other hand, considering the classification according to subject of legal regulation M. Swallowe, article 2121 of the criminal code of Ukraine under article 212 of this Code is relatively special, that is, one that was separated from General (article 212 of the criminal code) and provides for liability for conduct not previously regulated by the criminal law. So, we come to the conclusion that article 2121 of the criminal code of Ukraine is a relatively

${ }^{10}$ Kurash Y. Criminal liability for evasion of taxes, fees and other mandatory payments (analysis of the crime): abstract. Dis. for the Sciences. The degree candidate. Yuri. Sciences: spec. 12.00.08 "Criminal law and criminology; criminal Executive law". Kharkov, 1998. 18 p. 
special article 212 of the criminal code of Ukraine and the qualification is in competition with her. Simultaneous qualification under articles 212 and 2121 of the criminal code of Ukraine is possible only in the case of a real set of crimes.

Evasion from payment of the single contribution on obligatory state social insurance and insurance contributions on obligatory state pension insurance made by the official of the state- state enterprise, institution, organization, intentionally, for the purpose of obtaining any unlawful benefit for itself or another natural or legal person using official position contrary to the interests of the service, causing significant harm or causing serious consequences to the interests of the state protected by law, should be qualified, in our opinion, on the totality of crimes under articles 2121 and 364 of the criminal code of Ukraine. If such actions were committed by an official of a legal entity of private law, regardless of the organizational and legal form, they must be qualified under articles 2121 and 3641 of the criminal code of Ukraine.

In addition, one of the ways to avoid paying a single contribution to compulsory state social insurance and insurance contributions to compulsory state pension insurance is to commit it by forging the relevant documents (reporting, accounting or primary).

One of the ways of evasion from payment of a single contribution to compulsory state social insurance and insurance contributions to compulsory state pension insurance is described in the dispositions of articles 358 and 366 of the criminal code of Ukraine. On the other hand, in V. 2121.

The criminal code of Ukraine legislator has not placed any indication on the methods of committing this crime, which are both independent crimes, so the rules of overcoming the competition of part and whole in this case do not apply.

From the content item 14 of the Resolution of Plenum of the Supreme Court of Ukraine of 08.10.2004, No. 15 "On some issues of application of legislation on liability for evasion of taxes, duties and other obligatory payments", it follows that in the case when the evasion of taxes, duties (mandatory payments) or concealment committed by forgery, the actions of the guilty person must also be qualified under Art. 366 of the criminal code of Ukraine. Thus forgery of documents by the official can be qualified under art. 366 of the criminal code of Ukraine regardless of what responsibility (criminal or administrative) it will be brought for evasion of taxes, fees (mandatory payments). However the Information letter of the Supreme specialized court of Ukraine on consideration of civil and criminal cases no 223-286/0/4-13 from 12.02.2013 g. "About practice of application by courts of separate regulations of the substantive law regarding the 
qualification of evasion of tax committed by forgery" contains the following clarification: if the person with the purpose of evasion of taxes, duties (mandatory payments) commits forgery, which is one of the ways for such evasion, the consequences that led to the actual shortfall in the budget or state targeted funds of funds in the relevant dimensions are covered by the provisions of a specific part of the article 212 of the criminal code of Ukraine cannot simultaneously (doubly) be regarded as serious consequences in the understanding of part 2 of article 366 criminal code of Ukraine. In our opinion, a similar approach can be applied in case of evasion of payment of a single contribution to compulsory state social insurance and insurance contributions to compulsory state pension insurance due to the mentioned circumstances.

In addition, when delineating the crime under article 2121 of the criminal code of Ukraine from related encroachments, attention should be paid to the ratio of the investigated crime with the crime under article 192 "Causing major damage by deception or abuse of trust" of the criminal code of Ukraine. M. Panov notes that evasion from payment of obligatory contributions to the state is one of the ways of causing property damage to the state by deception or abuse of trust3. At the same time Y. Sukhov believes that the infliction of property damage by deception or abuse of trust and evasion of mandatory contributions are correlated as General and special rules, but this competition is partial or incomplete. In his opinion, for causing property damage by deception should be involved citizensentrepreneurs and persons equated to them (auditors, lawyers, private notaries) in the case of non-transfer to the budgets of the amounts of income tax from citizens, since such persons are not officials (office) ${ }^{11}$. According to V. Lysenko and P. Causing property damage by fraud or abuse of trust and evasion of mandatory contributions, do not compete with each other, but only have some similarities [6].

Undoubtedly, insurance premiums for compulsory state social and pension insurance is one of the types of mandatory contributions to the state. And it is money that must be paid as insurance premiums for compulsory state social and pension insurance, is the subject of a crime under article 2121 of the criminal code of Ukraine. The subject of the crime under article. 192 of the criminal code of Ukraine, there are other means to be paid (for services provided, use of property). In addition, the object of causing

11 Sukhov Y. Evasion of taxes, fees, other mandatory payments: problems of differentiation from related crimes and qualification in aggregate: abstract. Dis. for the Sciences. The degree candidate. Yuri. Sciences: spec. 12.00.08 "Criminal law and criminology; criminal Executive law". Kiev, 2000. P. 16. 
property damage by deception or abuse of trust may be the property from which the illegally obtained benefit.

Significant differences between articles 2121 and 192 of the criminal code of Ukraine can be traced in other elements of the crime (in particular, the object and the objective side), which indicates the correctness and validity of the position. V. Lysenko and P. Melnik concerning the ratio of these compositions of crimes.

Therefore, the crimes provided by articles 192 and 2121 of the criminal code of Ukraine are not in competition. In aggregate, they can be qualified only if an individual-payer of insurance premiums for compulsory state pension insurance simultaneously deceives the state and does not pay other payments, for example, for electric energy, utilities, etc. The main criterion for distinguishing the crimes provided for in these articles is the signs that are directly indicated in the dispositions of criminal law.

\section{CONCLUSIONS}

The article is devoted to a comprehensive and systematic study of the issues of criminal and legal protection of social and pension insurance. The paper considers the Genesis and foreign experience of criminal liability for evasion of payment of a single contribution to compulsory state social insurance and insurance contributions to compulsory state pension insurance, as well as analyzes the elements of the composition of this act (article 2121 of the Criminal code of Ukraine). The author analyzes the qualifying features of the composition of evasion from payment of a single contribution to compulsory state social insurance and insurance contributions to compulsory state-not pension insurance, as well as its delimitation from related crimes. According to the results of the study, a number of proposals were developed to improve criminal liability for a crime under article 2121 of the Criminal code of Ukraine.

\section{SUMMARY}

1. Qualifying signs of the crime provided by Art. 2121 of the criminal code of Ukraine, is the Commission of intentional evasion from payment of a single contribution to compulsory state social insurance and insurance contributions to compulsory state pension insurance, committed by prior agreement by a group of persons or, if the same acts have led to the actual non-receipt of funds in large amounts to compulsory state social insurance funds (part 2). Under the Commission of this crime on preliminary arrangement by group of persons should understand that that was committed on a preliminary agreement reached prior to the Commission of the crime 
two or more persons, made provided by the features of the subject of this crime, and who acted as pavilast and roles.

Especially qualifying signs of the crime provided by Art. 2121 .

The criminal code of Ukraine, is the Commission of this act by a person previously convicted for evasion of payment of a single contribution to compulsory state social insurance or insurance contributions to compulsory state pension insurance, as well as evasion, which led to the actual nonreceipt in the funds of compulsory state social insurance funds in particularly large amounts (part 3). At qualification of relapse evasion from payment of the uniform contribution on obligatory state social insurance and insurance contributions on obligatory state pension insurance transferred by part 3 of Art. 2121 UK of Ukraine, it is necessary to consider the outstanding criminal record of the person for this crime.

Subject to the adoption by the legislator out of offers on formation of structure of the crime provided part 1 of article 2121 of the criminal code of Ukraine, the formal definitions of the notes to this article for the future should be associated only with the Commission of evasion from payment of single fee for obligatory state social insurance and insurance contributions for obligatory state pension insurance in large and extra-large sizes.

2. Having studied questions of competition of norms at qualification, and also having analyzed such type of competition of criminal law norms as competition of the General and special norm, we can claim that article 2121 of the criminal code of Ukraine is a special article 212 of the criminal code of Ukraine. At the same time, article 364 and article 2121 of the criminal code of Ukraine do not correspond as a General norm and a special one, and are not in competition. Certain features have the qualification of evasion from payment of a single contribution to compulsory state social insurance and insurance contributions to compulsory state pension insurance by means of forgery.

Crimes under articles 192 and article 2121 of the criminal code of Ukraine are not in competition. In aggregate, they can be qualified only if an individual-payer of insurance premiums for compulsory state pension insurance simultaneously deceives the state and does not pay other payments, for example, for electric energy, utilities and the like.

\section{REFERENCES}

1. Andrushko P. Criminal law of Ukraine; edited By S. Matishevsky, S. Yatsenko, P. Andrushko. Kyiv: Yurinkom Inter 2015. P. 512.

2. Kozachenko I., Kostareva T., Kruglikov L. Crimes with qualified structures and their criminal-legal assessment. Yekaterinburg: publishing house of the Ural state University. Academy, 2014. P. 9. 
3. Kurash Y. Criminal liability for evasion of taxes, fees and other mandatory payments (analysis of the crime): abstract. dis. for the Sciences. the degree candidate. Yuri. Sciences: spec. 12.00.08 "Criminal law and criminology; criminal Executive law”. Kharkov, 1998. 18 p.

4. Lesniewski-Kostareva T. Differentiation of criminal responsibility. Theory and legislative practice. Moscow: NORMA, 2016. P. 230.

5. Leykina N. Personality of the criminal and criminal responsibility. L.: Publishing house University press, 1968. P. 129.

6. Resolution of the Plenum of the Supreme Court of Ukraine dated 08.10.2004 No. 15 "on certain issues of application of legislation on liability for evasion of taxes, fees and other mandatory payments". URL: http://zakono.rada.gov.ua/cgi-bino./laws/maino.cgi?regno.=v0015700-04.

7. Ostanin V. Qualification of evasion from payment of taxes, fees, other obligatory payments: autoref. dis. for the Sciences. the degree candidate. Yuri. Sciences: spec. 12.00.08 "Criminal law and criminology; criminal Executive law". Kiev, 2004. 20 s.

8. Sukhov Y. Evasion of taxes, fees, other mandatory payments: problems of differentiation from related crimes and qualification in aggregate: abstract. dis. for the Sciences. the degree candidate. Yuri. Sciences: spec. 12.00.08 "Criminal law and criminology; criminal Executive law”. Kiev, 2000. P. 16.

\section{Information about the author: Predmestnikov O. G., Doctor of Law, Professor,} First Deputy Head of the Main Territorial Department, Justice in the Kherson Region 42/14, Potiomkinska str., Kherson, 73040, Ukraine 